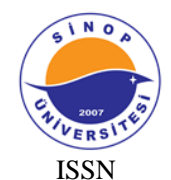

2547-989X
Sinop Üniversitesi

Sosyal Bilimler Dergisi
Sinop Üniversitesi Sosyal Bilimler Dergisi, 3 (1):143-168

Geliş Tarihi:20.02.2019

Kabul Tarihi:29.05.2019

https://doi.org/10.30561/sinopusd.529737

\title{
MÜSLÜMAN SEYYAHLARIN GÖZÜYLE BEYRUT ŞEHRİ (1890-1914)
}

\section{Firat KÜSKÜ*}

\section{Öz}

Seyahatnameler tarih yazımında kullanılan, birinci elden kaynaklardır. Anı, hatırat, mektup ve benzeri şekillerde yazılmış olan bu eserlere ihtiyatla yaklaşmakla beraber, başka kaynaklarda bulunmayacak ölçüde kıymetli bilgilere ulaşmak da mümkündür. Bu çalışmamızda, 1890-1914 tarihleri arasında Beyrut şehrine gelen ve gözlemlerini aktaran Müslüman yazarların eserleri üzerinden bir Beyrut portresi çizilmeye çalışılmıştır. Makalede ayrıca bu tarihlerden evvel ve bu tarihlerden sonra yazılan seyahatnamelere de atıfta bulunularak, yalnızca belirtilen tarih aralığında kalınmayıp, olayların evvel ve ahirine dair bahis açılmıştır.

Anahtar Kelimeler: Müslüman seyyahlar, Seyahatname, Beyrut, Osmanlı Arap coğrafyası, Sosyal hayat.

\section{The City of Beirut Through the Eyes of the Muslim Travelers (1890-1914)}

\begin{abstract}
Travelogues are the first-hand sources used in historiography. Although their importance, it needs to approach carefully. It is also possible to access valuable information that is not available in other sources. In this article, a portrait of Beirut will be drawn from the works of
\end{abstract}

* Arş. Gör., Sinop Ünv. Fen-Edebiyat Fakültesi Tarih Bölümü, firatkusku@gmail.com, https://orcid.org/0000-0003-4980-6219. 
Muslim writers who came to the city of Beirut between 1890-1914. The article will also mention the travelogues written before and after these dates.

Key Words: Muslim travellers, Travelogue, Beirut, Ottoman Arab geography, Social life.

\section{Giriş}

Günümüzde Lübnan sınırları içinde bulunan ve ülkenin başkenti olan Beyrut; Akdeniz'in doğu kıyısında kurulmuş, firavunlar döneminde dahi yerleşim yeri olduğu bilinen tarihi bir şehirdir. Beyrut ismi; Sâmi dil ailesine mensup Kenan dillerinde "be'erot" veya "beroe" şeklinde söylenerek günümüze ulaşmıştır. Kelime Sâmi dillerinde "kaynak" anlamına gelmektedir. ${ }^{1}$ Antik dönemde şehir; Biruta ve Berytus isimleriyle de anılmıştır. ${ }^{2}$ Şehir, tarih boyunca aldığı göçler ve ev sahipliği yaptığ1 farklı devletlerin bir ürünü olarak; çok uluslu, çok dinli, kozmopolit bir hüviyete sahip olmuştur. ${ }^{3}$ Beyrut; Lübnan'ın hatta Ortadoğu'nun, dini çeşitlilik ve kozmopolitlik açısından en renkli şehirlerinden birisidir.

Akdeniz kıyısındaki konumu nedeniyle; ticaret, ulaşım, kültür ve finans açısından önemli bir kent olagelen Beyrut'a ilk yerleşmelerin Fenikeliler zamanında olduğu düşünülmektedir. İlerleyen yıllarda bu topraklar; Misır, Asur, Babil ve İran hükümdarlarının da dikkatini çekmiş ve sıklıkla bu devletlerin istilasına uğramıştır. Büyük İskender döneminde önemli bir liman şehri olan Beyrut, İskender'in halefleri ve Misırlılar tarafından yönetildikten sonra Roma yönetiminde kalmıştır. Daha sonra, Hz. Ömer döneminde, 635 y1lından itibaren sürdürülen fetihler neticesinde

1 Besim Darkot, "Beyrut”, İslam Ansiklopedisi (İA), Milli Eğitim Basımevi, İstanbul 1979, c. II, s. 587.

2 Davut Dursun, "Beyrut”, Türkiye Diyanet Vakfi İslam Ansiklopedisi (DİA), İstanbul 1992, c. VI, s. 81 .

3 Beyrut hakkında ayrıntılı bilgi için bkz. Kürşat Çelik, "Osmanlı Hâkimiyetinde Beyrut (1839-1918)”, (Basılmamış Doktora Tezi Fırat Üniversitesi), Elazı̆̆ 2010; Zafer Orha, “Beyrut Vilayeti'nde Osmanlı İdaresi (1887-1909)”, (Basılmamış Doktora Tezi İstanbul Üniversitesi), İstanbul 2017; Fulya Düvenci Karakoç, “Şam ve Beyrut'ta Siyaset ve Modernleşme (1860-1914)”, (Basılmamış Doktora Tezi Uludağ Üniversitesi), Bursa 2011; Hayriye Beyazıdoğlu, "Salnamelere Göre Beyrut (H. 1310/M. 1893-H.1326/M.1908)", (Basılmamış Yüksek Lisans Tezi Gazi Üniversitesi), Ankara 2010. 
Ebu Ubeyde b. Cerrah'ın başkumandanlığında Yezid b. Ebu Süfyan ve kardeşi Muaviye'nin kumandasındaki ordular tarafından İslam topraklarına katılmıştır. ${ }^{4}$

Özellikle Muaviye bin Ebu Süfyan döneminde şehir her anlamda canl1l1k kazanmıştır. Muaviye'nin iskân politikası ile bölgeye Fârisî ve Yahudi halklar yerleştirilmiştir. Şehirde ilim hayatı canlanmış, birçok âlim yetişmiştir. ${ }^{5}$ Emevilerin y1kılmasıyla bölgede sırasıyla; Abbasiler, Tolunoğulları, Ihşıdiler ve Fatımiler hüküm sürmüştür. Beyrut ve Antakya gibi merkezler dâhil olmak üzere Doğu Akdeniz'de gelişen ticaretten elde edilen gelirler, XII. yüzyılda rastlanan tarıma dayalı vergilerin yerini almıştır. Bu nedenle, haçlılar da bölge ile ilgilenmişler ve burayı Kudüs Krallığı’na bağlamışlardır. ${ }^{6}$ Haçlı hâkimiyetinden sonra şehri Selahaddin Eyyubi’nin geri alması ve tekrar Haçlı hâkimiyeti kurulmasının ardından nihayet 1291 yılında bölgede Memluk hâkimiyeti başlamıştır. Bu hâkimiyet ise XVI. yüzyılda, Osmanlı fetihleri ile son bulmuştur.

İrili ufaklı birçok devlete ev sahipliği yapmış olan Beyrut, 1516 tarihinde Yavuz Sultan Selim'in Mısır seferi sonucu Osmanlı topraklarına katılıışır. ${ }^{7}$ Nitekim bu topraklar 400 yıl boyunca Osmanlı hâkimiyetinde kalmıştır. Bu süreç içerisinde Beyrut, uzun y1llar müstakil bir eyalet olmayıp; kimi zaman Sayda eyaletine, kimi zaman Şam eyaletine bağlı bir sancak olmuştur. Müstakil bir eyalet haline gelmesi ise 19. yüzyılın son çeyreğinde gerçekleşmiştir. Yüzyılın başında adeta bir köy olan Beyrut, yüzyılın sonuna gelindiğinde ise bölgenin ticaret limanı olmak için birbiriyle yarışan kıyı şehirleri arasından sivrilerek, imparatorluğun önde gelen liman kentlerinden biri haline gelmiştir. ${ }^{8}$

4 Mustafa L. Bilge, "Lübnan”, Türkiye Diyanet Vakfi Íslam Ansiklopedisi (DİA), Ankara 2003, c. XXVII, s. 244.

5 Joseph Hell, "Beyrut", İslam Ansiklopedisi (IAA), İstanbul 1961, c. II, s. 587.

6 R. Stephen Humpreys, "XIII. Yüzyılda Eyyûbîler, Memlûkler ve Latin Doğu”, (Çev. Mustafa Kılıç), Cumhuriyet Illahiyat Dergisi, Sivas 2007, Sayı: XI/1, s. 361.

7 Nikolay İvanov, Osmanlı'nın Arap Ülkelerini Fethi (1516-1574), (Çev. İlyas Kemaloğlu ve Rakhat Abdieva), Türk Tarih Kurumu, Ankara 2013, s. 33.

8 Bruce Masters, Osmanlı Imparatorluğu'nun Araplarl (1516-1918) Sosyal ve Kültürel Bir Tarih, (Çev. Feray Coşkun), Doğan Kitap, İstanbul 2017, s. 176. 
Osmanlıların yerel ananeleri mümkün olduğunca sürdürme politikaları kapsamında, mahalli idarelere çok fazla dokunmadıkları, buradaki yönetim şeklini mümkün oldukça değiştirmedikleri bilinmektedir. Beyrut’ta da aynı durum geçerli olup; yerel emirlerin sözde Sayda valisine bağlı olmakla beraber, yarı bağımsız bir idare yürüttükkleri görülmektedir. Şehirde bu yarı bağımsız idareyi elinde tutanlar ise; Dürzî ve Marunîlerdir. XI. yüzyılda ortaya çıkan, Şiiliğin İsmailiyye kolundan olan ve Fatımi halifesi El- Hâkim bi-Emrillah'1 ilah kabul eden Dürzîler ${ }^{9}$ ve kökleri V. yüzyıldaki kurucuları John Maron'a dayanan, Katolik kilisesinin doğu ayin usulünü benimseyen Marunîler, ${ }^{10}$ Beyrut'ta idari, iktisadi ve sosyal yaşama yön veren iki önemli millettir. ${ }^{11} \mathrm{Bu}$ gruplar arasında yönetim erkini elde tutmak hususunda her daim çatışmalar yaşanmıştır. Bölge idaresine başlangıçta Dürzîler hâkim iken sonraları bu üstünlük Marunîlerden Sihab ailesine geçmiştir. ${ }^{12}$ Bu grupların devletin kontrolünü ele alma çabaları ve iç karışıklıklar sırasında, 1772'de Rus donanmasına ve Zahir Ömer'e karşı Beyrut'u savunan Cezzar Ahmed Paşa, Sayda valiliğine getirilerek bölgenin yeni gücü haline gelmiştir. ${ }^{13}$ Nitekim Cezzar Ahmed Paşa'nın valiliği döneminde (1776-1785) bölgede Osmanlı hâkimiyeti yeniden tesis edilmiştir.

1831-1841 yılları arasında, Osmanlı tarihine damgasını vuran Mısır valisi Kavalalı Mehmet Ali Paşa, Beyrut'u kontrolü altına almıştır. Osmanlı Devleti ile isyankâr paşanın oğlu İbrahim Paşa yönetimindeki kenti geri almak için yapılan savaşlarda şehir harap olmuştur. Bundan sonra bölge, Düvel-i Muazzama'nın çıkar çatışmaları arasında çalkantılı dönemler geçirmiştir. Özellikle 1860-1861 y1llarında yaşanan Dürzî-Marunî çatışmalarında binlerce insan katledilmiştir. ${ }^{14}$

9 John R. Hinnells, The Penguin Dictionary of Religions, Penguin Books, London 1995, s. 141.

${ }^{10}$ Hinnells, The Penguin Dictionary of Religions, s. 300.

11 Millet kelimesi; Osmanlılarda klasik dönemden itibaren dini zümreleri ifade etmek için kullanılmıştır. Ayrıntılı bilgi için bkz. İlber Ortaylı, "Osmanlılar'da Millet Sistemi”, Türkiye Diyanet Vakfi Íslam Ansiklopedisi (DIA), İstanbul 2005, c. XXX, s. 66-70.

12 Erdoğan Keleş, "Cebel-i Lübnan'da İki Kaymakamlı İdare Düzeninin Uygulanması ve 1850 Tarihli Nizamname", Tarih Araştırmaları Dergisi, Cilt: XXVII, Sayı: 43, s. 132.

13 Mustafa Güler, Cezzar Ahmed Paşa ve Akka Savunması, Çamlıca Basım Yayın, İstanbul 2013, s. 62.

14 Tayyib Gökbilgin, “1840’tan 1861 'e Kadar Cebel-i Lübnan Meselesi ve Dürzîler” Belleten, Ankara 1946, Cilt: X, Say1: 40, s. 641-691. 
Buna mukabil yapılan idari reformlar ile 1861 yılında Lübnan Nizamnamesi kabul edilmiş ve Cebel-i Lübnan, Beyrut vilayetinden ayrı bir statüye sahip olmuştur. ${ }^{15}$ Eyaletin Hıristiyan bir idareci altında; Marunî, Dürzî, Rum ve Müslüman temsilcilerden oluşan bir heyet tarafından yönetilmesi kararlaştırılmıştır. ${ }^{16}$ Böylece Lazkiye, Trablus, Akka ve Nablus sancaklarını kapsayan müstakil bir vilayet haline gelen Beyrut, bu şekilde I. Cihan Harbi’nin sonuna kadar (1918) Osmanlı yönetiminde kalıp, bundan sonra Fransa hâkimiyeti altına girmiştir. 1943'te bağımsız Lübnan devleti kurulana kadar manda idaresi altında yaşayan şehir, bağımsızlığın kazanılmasıly beraber Lübnan'ın başkenti olmuştur.

Tarihi hakkında kısaca bilgi verdiğimiz Beyrut şehrini seyyahların gözünden anlatırken, yoğunluklu olarak yararlandığımız seyyahlar; Şibli Numani (1892), Şerafeddin Mağmumi (1895), Babanzade İsmail Hakk1 (1908), Ali Suad (1911) ve Yusuf Akçura (1913)'dır. Bölümler kendi içinde kronolojik olarak sunulduğundan tarihsel bütünlük korunmuştur. Makalede yalnızca yukarıda zikredilen seyyahların değil, bu isimlerden önce veya sonra bölgeye gelen seyyahların eserlerine de değinilmiştir. ${ }^{17}$

\section{Seyyahlar ve Ulaşım Şekilleri}

Seyahatnamelerde geçen Beyrut mefhumuna değinmeden evvel, kısa da olsa seyyahları tanımak elzemdir. Zira hiçbir yazı, yazarın şahsiyetinden bağımsız düşünülemez. Yazılanlar adeta, yazarların mutfaklarında pişen ve tadını kendi isteklerine göre belirledikleri yemekler gibidir. İşte bu nedenle makalede, müelliflerin hayatları ve neden Beyrut'a gittikleri hakkında kısaca malumat verilmiştir.

15 İlber Ortayl, Tanzimat Devrinde Osmanlı Mahalli İdareleri (1840-1880), Türk Tarih Kurumu, Ankara 2018, s. 52.

${ }^{16}$ Fahir Armaoğlu, 19. Yüzyll Siyasi Tarihi, Timaş Yayınları, İstanbul 2014, s. 277.

${ }^{17}$ İsmi zikredilen seyyahların dışında Cenab Şahabeddin, Mehmet Behçet ve Refik Temimi de Beyrut'a gelerek gözlemlerini yazıya döken önemli şahsiyetlerdir. Bu isimlerin eserlerinin basım tarihi, makalenin tarih aralığı dışında olduğundan eserlere yalnızca değinilmiştir. Bu eserler için bkz. Cenab Şahabeddin, Beyrut, Filistin ve Nablus İzlenimleri 1918, (Haz. Tayfun Haykır), Ötüken Neşriyat, İstanbul 2015; Mehmed Refik Temimî ve Mehmed Behcet, Beyrut Vilayeti I. Cenub Kısmı(1333-1335), Beyrut Vilâyet Matbaası, Beyrut 1917. 
Hindistanlı bir âlim ve tarihçi olan Şibli Numani ${ }^{18}$ (1857-1914), tarihe duyduğu ilgi nedeniyle İslâm dünyasındaki büyük kütüphaneleri dolaşmış, bu amaçla Türkiye, Suriye ve Mısır'ı ziyaret etmiştir. Numani’nin Beyrut'ta bulunduğu tarih takriben 1892'dir. Bu nedenle 19. yüzyılın son çeyreğine dair önemli bir kaynaktır. İlim adamı olması hasebiyle daha çok Beyrut'un eğitim ve kültür faaliyetleri üzerinde durmuş, İstanbul'a geldiğinde ise Sultan II. Abdülhamid tarafından mecidiye nişanına layık görülmüştür.

İttihat ve Terakki cemiyetinin önemli üyelerinden olan Şerafeddin Mağmumi ${ }^{19}$ (1860-1931) tıbbiye mezunudur. Doktor olarak kolera hastalığını araştırma komisyonunda görev almış, 1895-1896 tarihlerinde Suriye'de tetkiklerde bulunmuştur. Beyrut tecrübeleri, bir İttihat Terakki mensubunun ve tıp doktorunun gözünden olması hasebiyle, incelenen diğer eserlerden farklı bir hüviyete sahiptir.

Ali Suad ${ }^{20}$ (1869-1933); şair, romancı, öykücü, gezi yazarı, düşünür ve çevirmendir. Bir Osmanlı bürokratı olarak Necid mutasarrıflığına tayin edilmesiyle ${ }^{21}$ makalemizin içeriklerinden biri haline gelecek olan eserini yazmıştır. Eserinin diğer seyahatnamelerden ayrılan kısmı, yolda yazılmış olmasıdır. Bu açıdan bir anı, bir günlük gibidir. Samimi ve sade bir dil ile yazdığı eserinin Beyrut'la ilgili kısımları değerlendirilmiştir.

Babanzade İsmail Hakk122 (1876-1913), Süleymaniye merkezli Baban ailesine mensuptur. Bağdat mebusluğu yapmış bir Osmanlı devlet adamıdır. Makalemiz

18 Şibli Numani hakkında ayrıntılı bilgi için bkz. Anıs Ahmad, "Şibli Numani”, Türkiye Diyanet Vakfi İslam Ansiklopedisi (DİA), İstanbul 2010, c. XXXIX, s. 126-127.

${ }^{19}$ Şerafeddin Mağmumi hakkında ayrıntılı bilgi için bkz. İsmail Türkoğlu, "Şerafeddin Mağmumi”, DİA, c. Ek-2, s. 167-169; Nazım H. Polat, Bir Jöntürk'ün Serüveni: Dr. Şerafettin Mă̆mumi-Hayatı ve Eserleri, İstanbul 2002; A. Süheyl, "Doktor Şerafettin Mağmûmî 1870-1937”, Poliklinik Tıbbi Mecmuast, İstanbul 1934, Sayı: IX, s. 1-5.

${ }^{20}$ Ali Suad hakkında ayrıntılı bilgi için bkz. Ali Birinci, "Mehmed Suad Nam-i Diğer Ali Suad'ın Hikâyesi”, İstanbul Araştırmaları Dergisi, İstanbul 1998, Sayı: IV, s. 159-180.

21 Başbakanlık Osmanlı Arş. (BOA), İrade-Dâhiliye (İ.DH.) 1477/37 17 N 1327/02Ekim 1909.

22 Babanzade İsmail Hakkı hakkında ayrıntılı bilgi için bkz. Davut Hut, "II. Meşrutiyet Döneminde Bir Osmanlı Entelektüeli Babanzade İsmail Hakkı (1876-1913)”, Tarihimizden Portreler Osmanlı Kimliği, (Ed. Zekeriya Kurşun ve Haydar Çoruh), ORDAF Yayınları, İstanbul 2013, s. 101-123. 
için değerli olan çalışması ise, 1908 'de gittiği Irak gezilerini anlattığı ve Tanin gazetesinde yayınlattığı mektuplarıdır. Bir Osmanlı entelektüelinin gözünden Beyrut'u görmek için kendisinin çalışması makalenin omurgalarından olacaktır.

Yusuf Akçura $^{23}$ (1876-1935); Tatar asıllı Türk yazar, siyasetçi, tarihçi, milletvekili, Türk Tarih Kurumu başkanlığı yapmış olan bir entelektüeldir. Akçura çok kıymetli bir yazar ve siyasetçi olmasının yanında, 1913 senesinde yaptığı Suriye ve Filistin seyahatleri esnasında Tanin (daha sonra Renin) gazetesine yolladığı mektuplar hasebiyle makalemizin konularından biri haline gelmiştir. Eserinin diğer seyahatlerden ayrılan yönü ise; eğitim ve bilim adına incelemelerde bulunması, okulları tek tek gezerek müşahede etmesi, gördüğü sorunlara ürettiği çözümleri tafsilatlı bir şekilde yazıya dökmüş olmasıdır.

İsimlerini zikrettiğimiz seyyahlar Beyrut'a muhtelif şekillerde ulaşmışlardır. Şehre, Anadolu üzerinden kara yolu ile ulaşmak eski çağlar için yegâne seçenekti. Ancak yakınçağ seyyahları (19. yüzyıl ve sonrası) Beyrut'a ulaşım için daha konforlu ve hızlı olan vapuru tercih etmişlerdir. Şibli Numani, İzmir-Rodos-Kıbrıs hattını takip eden vapur ile Beyrut'a ulaşmıştır. ${ }^{24}$ Şerafeddin Mağmumi ise İskenderun üzerinden Hıdıviyye şirketinin Şarkiye isimli vapuru ile Beyrut'a ulaşmıştır. Vapur önce Mersin'e ardından Trablusşam'a uğrayarak Beyrut'a varmıştır. ${ }^{25}$ Mağmumi’nin kullandığg vapur ismen Hıdiviyye olsa da sermayesi İngilizlerin elinde olan bir şirkete

23 Yusuf Akçura hakkında ayrıntılı bilgi için bkz. François Georgeon, Türk Milliyetçiliğinin Kökenleri-Yusuf Akçura 1876-1935, (Çev. Alev Er), Ankara 1986; Ahmet Temir. Yusuf Akçura, Ankara 1987; Muharrem F. Togay, Yusuf Akçura'nın Hayatı, İstanbul 1944; Samet Ağaoğlu, Babamın Arkadaşları, İstanbul 1998; Emel Esin, “Akçuraoğlu Yusuf Bey’e Dair Hatıralar”, Ölümünün Ellinci Yılında Yusuf Akçura Sempozyumu Tebliğleri, Ankara 1987; Harnit Z. Koşay, "Yusuf Akçura", TTK Belleten, Ankara 1977, Cilt: XLI/162, s. 389-400; M. Şükrü Hanioğlu, "Türkçülük", Tanzimat'tan Cumhuriyet'e Türkiye Ansiklopedisi (TCTA), c. V, s. 1397.

24 “Gemi, Izmir'e, Rodos'a, Kıbrıs'a uğrayarak 7. günde Beyrut'a ulaştı." Şibli Numani, Anadolu-Suriye-Misır Seyahatnamesi, Risale Yayınları, İstanbul 2002, s. 132.

25 “İskenderun'da on gün kadar kaldıktan sonra Hıdıviyye Kumpanyası'nın Şarkiye Vapuruna binerek Beyrut'a doğru hareket ettik. Vapur önce Mersin'e gitti, oradan Trablusşam’a doğruldu. Sabahleyin güverteye çıktığım zaman "Şarkiye" iri fakat ölü dalgaları yarıp etrafa köpükler saçarak Cebeli Lübnan sahilini izleyerek ilerliyordu. Nihayet uzaktan beyaz bir leke seçildi. "Beyrut" dediler." Şerafeddin Mağmumi, Bir Osmanlı Doktorunun Seyahat Anıları Yüzyıl Önce Anadolu ve Suriye, (Çev. Cahit Kayra), Boyut Yayın Grubu, İstanbul 2008, s. 241. 
aittir. Bölgeye giden birçok seyyah bu durumdan yakınırken, bölge halkı da bu durumdan hoşnut olmayarak İngiliz bandıralı bir Hıdiviyye Kumpanyası görmek istememiştir. $^{26}$

İsmail Hakkı Babanzade, Galata rihtımından bindiği Mesajari Maritim (Compagnie des Services Maritimes des Messageries Nationales) şirketine ait olan bir vapur ile Beyrut'a gitmiştir. On beş günde bir Galata'dan kalkan bu vapur, 19. yüzyılın II. yarısında Mesajari Maritim şirketine bağl1 130'a yakın vapurdan biriydi. ${ }^{27}$ Vapurun özelliği ise Beyrut'a en kısa yoldan giden şirket olmasıydı. Bu nedenle Beyrut'a gitmek isteyen halkın yoğun ilgi gösterdiği ve vapurda oturulacak yer dahi olmadığı sıklıkla dile getirilmiştir. ${ }^{28}$

Yusuf Akçura da İstanbul'dan kalkan bir vapur ile Beyrut'a ulaşan seyyahlardandır. Akçura, Fransız gemisiyle Beyrut'a giderken bu hususta bir eleştiride bulunmaktan da geri durmamıştır. Daha evvel İstanbul'dan Beyrut'a Osmanlı şirketlerinin gidip geldiğini belirtirken artık bu sahanın tamamen Fransız, Rus, Avusturya ve İngiliz şirketlerine kaptırıldığından dem vurmuştur. ${ }^{29}$ Ali Suad ${ }^{30}$ ve Cenab Şahabeddin $^{31}$ de diğer seyyahlar gibi, deniz yolu ile Beyrut'a gitmişlerdir.

${ }^{26}$ Metin Ünver, “Courtgi (Gürcü) Bahr-i Sefid (L'egee) Vapur Kumpanyası 1883-1911”, Çanakkale Araştırmaları Türk Yıllı̆̆ı, Yı1: 2018, Sayı: 24, s. 197.

27 Süleyman Uygun, Osmanl Sularında Rekabet (Mesajiri Maritim Vapur Kumpanyası 1851-1914), Kitap Yayınevi, İstanbul 2015, s. 355-358.

28 'On beş günde bir en kestirme yollardan Beyrut'a giden Mesajeri Maritim Kumpanyası'nın, Galata rıhtımına yanaşan Nijer vapuruna bindim. Bütün Suriye ve Irak yolcuları Beyrut'a en kısa zamanda giden bu vapurun hareket gününü iple çekerler. Onun için koca vapurda ne boş bir yatak ne oturulacak bir yer kalmıyor; mahşer ah!’' İsmail Hakkı Babanzade, Beyrut'tan Kuveyt'e Irak Mektuplarl, Büke Yayınları, İstanbul 2002, s. 19.

29 "İstanbul' dan Suriye'ye Fransız, Rus Avusturya ve "Hidiviyye" isimli İngiliz şirketinin gemileri gidiyor. İtalyan ve Balkan savaşlarından evvel, iki üç ayda bir Türk gemisi de buraya gelip gidiyormuş, şimdi artık o da yok. Ben Fransız gemisiyle geldim.” Yusuf Akçura, Suriye ve Filistin Mektuplarl, Ötüken Neşriyat, İstanbul 2016, s. 18.

30 "Bir sabah erkenden güneşin ilk ziya-1 gülfami sahili iten yüce dağların tepelerinde uçuşurken vapur da Beyrut limanına giriyordu. "Ali Suad, Suriye, Irak, Necid ve Hicaz Seyahatlerim, Taş Mektep Yayınevi, İstanbul 2015, s. 35.

31 “Uzak limanlardan gelirdiniz; sabırsız gözlerle Lübnan eteklerinde Beyrut'u ararken birdenbire saf ve pırıldayan bir sema altında pürziya (1şıklı), pürelvan (rengârenk), pürzehep (parlak), pürevrak (yapraklı), pürezhar (çiçekli) güzel Beyrut karşınıza çıkardı." Şahabeddin, Beyrut, Filistin ve Nablus İzlenimleri 1918, s. 68. 
Görüldüğü üzere, incelediğimiz yakınçağ seyyahlarının hepsi şehre vapur ile ulaşmışlardır. Burada dikkat çeken husus, vapur işletmelerinin yabancıların elinde olmasıdır. Özellikle; İngiliz ve Fransız şirketlerinin bu işletmeleri tekellerinde tuttukları görülmektedir. Devletin ulaşım gibi önemli bir sahayı yabancı işletmelere bırakmış olması, hem seyyahlarca hem de bizce eleştirilen bir husus olmuştur.

\section{Coğrafya, İklim ve Mimari}

Beyrut'a dair ilk bilgiler, milattan önce 15. yüzyıla değin uzanmaktadır. Şehir, beş bin yılı bulan tarihi ile dünyanın en yaşlı şehirleri arasındadır. Suriye'nin, özellikle de Şam'ın iskelesi sayılmaktadır. Ticaret merkezi, ma'mur (bayındır), bakımlı ve güzel bir şehirdir. Genellikle kuru bir havası vardır. Şehir suyunu Nehrü’lKelb'den alır. ${ }^{32}$ Beyrut vilayeti; kuzeyinde Halep, doğusunda Suriye vilayeti, güneyinde Kudüs-i Şerif Mutasarrıflığı ve batısında Bahr-i Sefid (Akdeniz) ile çevrilidir. Yüzölçümü $12.000 \mathrm{~km}^{2}$ 'dir. Vilayet dâhilinde boydan boya Lübnan dağları silsilesi uzanmakta olup; Cebel-i Santeyn, Kermel ve Tabur dağları başlıca tepeleridir. Nehrü'l-Kelb, Nehrü'l-Esbed, Nehr'ül-Kebir ve Nehr'ül-Munkatı gibi çaylar ve Asi ile Yordan nehirleri; Taberiye ve Havle gölleri vardır. Kıyılarında kayalık plajları, kumlu sahilleri ve uçurumları yan yana yer almaktadır. ${ }^{33}$

14. yüzyılda Beyrut'a gelen Ebü'l Fida, Beyrut'ta iki kale ve bolca meyve tarlaları bulunduğunu belirtmiştir. ${ }^{34}$ Ebü’l Fida'dan yaklaşık üç asır sonra aynı bölgeyi gezen meşhur seyyah Evliya Çelebi ${ }^{35}$ Beyrut'un Sayda eyaletinde bir sancak

32 Binbaşı M. Nasrullah, Kolağası M. Rüşdü, Mülazım M. Eşref, Memalik-i Şahaneye Mahsus Mükemmel ve Mufassal Atlas (Osmanlı Atlası), OSAV Osmanlı Araştırmaları Vakfı, İstanbul 2003, s. 94.

33 Nasrullah, Rüşdü ve Eşref, Memalik-i Şahaneye Mahsus Mükemmel ve Mufassal Atlas (Osmanlı Atlast), s. 95.

34 Ayrıntılı bilgi için bkz. Ebü'l Fida, Ebü'l Fida Coğrafyası, (Çev. Ramazan Şeşen), Yeditepe Yayınevi, İstanbul 2017; Kâtip Çelebi, Keşefüzzunûn, Tarih Vakfı Yurt Yayınları, İstanbul 2017, c. I, s. 468-469; Mehmed Şemseddin Günaltay, Íslam'da Tarih ve Müverrihler, Kitabevi, İstanbul 1991, s. 217-220.

35 Evliya Çelebi hakkında ayrıntılı bilgi için bkz. Mücteba İlgürel, "Evliya Çelebi”, Türkiye Diyanet Vakfi İslam Ansiklopedisi (DİA), İstanbul 1995, c. XI, s. 529-533. 
olduğunu ve 600 köy ile sekiz nahiyesinin bulunduğunu belirtmekte, limanın iki ucunda birer kalenin ve esas Beyrut Kalesinin iç kısmında 2600 evin yer aldığını yazdıktan sonra mimari hakkında bilgi vermektedir. Buna göre; manastırdan camiye dönüştürülen Ulu Camii, güzel bir cami olan Asaf Paşa Camii, Mir Münzir ve Amri Camii şehirde zikredilmesi gereken camilerdir. Evliya Çelebi'nin varlıklarından bahsettiği on yedi medrese, sekiz sıbyan mektebi, dört hamam, yedi çeşme, üç yüz dükkân, kırk kahvehane ve sekiz ticaret hanı ise Beyrut'un bu asırda bile birçok açıdan gelişmiş bir şehir olduğunu göstermektedir. ${ }^{36}$

19. yüzyılın son çeyreğinde şehri gezen Fransız yazar Gerard De Nerval, Beyrut için, "tertemiz, gölgeli ve sessiz bir manzara; İsviçre göllerinden birinden çıkmış gibi bir Alp Dağları görüntüsü; işte sakin bir havada Beyrut! Yumuşak okşamalarla birbiri içinde eriyen Avrupa ve Asya burası!”37 diyerek şehre duyduğu hayranlığı dile getirmiştir.

Şibli Numani, eski ve yeni şehri karşılaştırdıktan sonra Beyrut'un coğrafi yapısı üzerine şunları yazmıştır:

"Bu şehir Suriye vilayetinin bir liman şehri ve bir istasyon şehri olduğundan, ayn zamanda Suriye şehirleri içinde kültürün ve medeniyetin merkezi kabul edilir. ${ }^{38}$ Şehrin eski bölümü son derece bozuk ve virandir. Yollar, caddeler, sokaklar daracık ve çukurlarla doludurlar. Evler basık ve havasızdırlar. Ama şehrin yeni bölümü son derece şaşaalı ve güzel görünümlüdür. Restoranlar, oteller, çayhaneler çokçadır. Çayhanenin biri denizin ortasına yapılmış ve harika görüntüsü vardır. İklim ve hava bir ölçüde nemlidir. Buna rağmen herkesin dediğine göre, buranin havası sağllk için çok faydallymış. Hatta o derecede ki; başka başka yerlerden hava değişimi için insanlar buraya gelirlermişs. Buranın iklimi çok nemli olduğu için ben devamlı yorgun ve halsiz kaldım. ",39

${ }^{36}$ Evliya Çelebi, Günümüz Türkçesiyle Evliya Çelebi Seyahatnamesi, (Haz. Seyit Ali Kahraman), Yap1 Kredi Yayınları, İstanbul 2003, c. IX, s. 446-450.

37 Gerard De Nerval, Doğu'da Seyahat, (Çev. Selahattin Hilav), Yapı Kredi Yayınları, İstanbul 2014, s. 362.

38 Numani, Anadolu-Suriye-Misır Seyahatnamesi, s. 133.

39 Numani, Anadolu-Suriye-Misir Seyahatnamesi, s. 134. 
İşte tam da bu noktada, havası iyi geldiği için buraya gönderilen birkaç kişiden bahsetmek konuyu daha sağlam bir düzleme oturtacaktır. Beyrut'un havasının hastalıklara iyi geldiği hususundaki kanının, devlet görevlileri arasında hayli yaygın olduğu görülmektedir. Bu nedenle, birçok memur ve bürokrat Beyrut'a gönderilmiştir. Örneğin; 27 Aralık 1890'da Zor Mutasarrıflığı Aşar Kaymakamı Mehmed Salahaddin Efendi, hastalığının tedavisi için iki ay süreyle Beyrut'a gönderilmiştir. ${ }^{40}$ Bundan başka; Pazarcık Kaymakamı Mehmed Efendi, ${ }^{41}$ Şam'da görevli polis memuru Kandilci Hüseyin, ${ }^{42}$ Payas Kaymakamı Elvan Bey, ${ }^{43}$ Beni Saab Kaymakamı Necib Nadir Efendi, ${ }^{44}$ İşara Kaymakamı Mahmud Selahaddin Bey ${ }^{45}$ ve Trabzon Maiyyet Müdürü Mehmet Emin Efendi ${ }^{46}$ tedavi amaciyla Beyrut'a gönderilen memurlardan sadece birkaçıdır. Arşiv belgeleri incelendiğinde imparatorluğun dört bir yanından, çok sayıda görevlinin tedavi yahut hava değişimi amacıyla buraya gönderildiği görülmektedir.

Ancak ilerleyen y1llarda buraya gelen Doktor Şerafeddin Mağmumi, bu konuda diğer verilere zıt olarak şunları yazmaktadır: "Beyrut eskiden beri veremlilere hava değişimi için tavsiye edilmekte iken son zamanlarda bu ününü yitirmeye başlamıştır. Çünkü rutubetin veremlilere yarar yerine zarar verdiği ve hatta hastalığın gidişini hızlandırdığı yerel hekimlerin istatistikleriyle saptanmıştır." ${ }^{47}$ Bir tıp doktoru olarak Mağmumi'nin bu konudaki görüşü dikkate değerdir.

Şehrin coğrafi özellikleri üzerine Babanzade'nin betimlemeleri ise oldukça canlıdır:

"Beyrut, Akdeniz ile Suriye çölleri arasında, doğanın yüce bir rıhtım gibi uzattığl Cebeli Lübnan siradağlarının eteğinde kurulmuştur. Esasen eski ve yeni adı

\footnotetext{
40 BOA, Dâhiliye Mektubi Kalemi (DH. MKT.), 1796/28 17 CA 1308/29 Aralık 1890.

41 BOA, DH. MKT. 198/85 16 B 1311/23 Ocak 1894.

42 BOA, DH. MKT. 270/63 09 S 1312/12 Ağustos 1894.

43 BOA, DH. MKT. 1672/64 14 RA 1307/08 Kasim 1889.

44 BOA, DH. MKT. 1768/27 22 S 1308/07 Ekim 1890.

45 BOA, DH. MKT. 1787/123 19 R 1308/02 Aralık 1890.

46 BOA, DH. MKT. 2683/80 21 ZA 1326/15 Aralık 1908.

47 Mağmumi, Bir Osmanlı Doktorunun Seyahat Anıları Yüzyıl Önce Anadolu ve Suriye, s. 246.
} 
ile ikiye ayrılmış olup, eski Beyrut'un binaları yüksek ve kemerli, sokakları dar ve çoğu yerlerde üstü örtülü olduğu için karanlık ve pis kokuludur. Yeni Beyrut'un binaları taştan ve zarif, caddeleri geniş ve ferahtır. Kırmızı kumsal üzerine yayılmış olup, deniz kıyısındaki vahşi kaya döküntüsü doğal bir kordon oluşturuyor. Arazi doğuya doğru yükselir ve birkaç tepeyi kapsar. Batı ve kuzeyi açık, güneyi Cebeli Lübnan ile çevrilidir. Yöresinde durgun sular yoktur. Havası ılımlı ise de rutubetin çokluğu unutulmamalıdır. Bu da yerinin kumsallı̆̆ ile arkasının yüksek dağlarla kapatılmış olmasından ileri geliyor. Yağmur da sık yağarmış. Yazın ısı 30-35 derece ise de rutubetin fazlalı̆̆ından pek güç tahammül ediliyor. Kışın da sıfıra düşermiş. Şehrin konumunda bir güzellik, bilhassa civarında insana ferahlık veren bir paklık olduğunu itiraf etmek gerekir. Nehr-i Beyrut ve Nehr-i Kav civarı ferahfeza bahçeler, düzenli çamlıklar ile çevrili olduğu gibi, gayet ferahlık veren Fıstıkiye Bahçesi, Beyrut şehriyle cidden uyumlu bir ormanlık sayllabilir. ${ }^{48}$

Evliya Çelebi bu ormanlıkiçin "bir azim ormandır ki, içinde âdem kaybolur"49 der. Babanzade şehrin coğrafi özellikleri hakkındaki sözlerine şöyle devam eder:

“Beyrut'un baş tarafi yönünün görülmedik manzaralarl, Güvercinlik Mağarası dedikleri Roşe mevkii ki sahilde gayet çekici ve gösterişli yüksek kayaların durmadan vuran dalgalar ile aşınıp oyularak gayet şairane kovuklar meydana getirmesinden ibaret; seyrine doyulmaz, benzersiz bir manzara teşkil eder. Beyrut'un diğer bir seçkin özelliği de dă̆ın eteğinde olmasıdır. Şehir halkı adeta her gün Boğaziçi’ne gider gibi sayfiyelerine gidip gelerek, aynı zamanda hem dağın temiz havasından ve hem de günlük ticaretinden yararlanır. "50

Ali Suad, bağ ve bahçeler için şöyle yazar: "Ufak ve fakirane bahçeler solda, deniz sağda, yola devam edildi. Bu bahçelerde ipek böceğine mahsus dutfidan ve ağaçları ile üzüm kütükleri, incir ağaçları ve bazı mezruat vardı. Deniz sahili güzel, arızalı oymalı ve ufak dalgaların köpüklü çarpışmalarıyla hoş bir manzara arz ediyordu." 51

48 Babanzade, Beyrut'tan Kuveyt'e Irak Mektuplarl, s. 26.

49 Evliya Çelebi, Seyahatname, c. IX, s. 420.

50 Babanzade, Beyrut'tan Kuveyt'e Irak Mektuplar, s. 26-28.

51 Suad, Suriye, Irak, Necid ve Hicaz Seyahatlerim, s. 37. 
Bahsettiğimiz seyyahlardan daha geç bir tarihte bölgeye gelen Cenab Şahabeddin ise coğrafi özellikleri şöyle betimler: "Dağlar, güneş ve deniz. Bu üç büyüklük Beyrut'u özetliyor. Batı ufkunda mavi deniz dalgalanır, doğu ufkunda yaldızlı ve parlak tepeler, mor ve lacivert sırtlarına dayanmış beyaz, temiz, taş binalar: İște Beyrut!"52

Deniz kıyısında bulunan bu verimli topraklarda; turunçgiller, tütün, arpa, zeytin, buğday ve susam da yetiştirilir. Hatta buradan padişaha portakal gönderildiği dahi olmuştur. ${ }^{53}$ Beyrut'un bağ ve bahçelerinin zenginliği, çoğu seyahatnamede geçmektedir. Ancak bu topraklarda hububat yetişmemesi ve hububat ihtiyacının kara veya deniz yoluyla dışarıdan sağlanması, zaman zaman bölge için sorun teşkil etmiştir. Özellikle I. Dünya Savaşı sırasında, harp müddetince abluka altında kalan şehirde birçok insan bu nedenle hayatını kaybetmiştir. ${ }^{54}$ Yabancı basında bu konuda Cemal Paşa'nın kasten Hıristiyan halkı aç bıraktığına dair haberler çıksa da işin aslı bahsettiğimiz gibi hububat sorunudur. Son olarak, Beyrut’ta Osmanlı döneminde yaptırılan kamu binaları bugün dahi hizmet vermektedir, en meşhurları; Askeri Hastane (1860), Saat Kulesi (1897) ve Mecidiye Camii (1773)'dir.

\section{Nüfus ve Demografik Yapı}

Nüfus ve demografik yapı hususunda seyahatnamelerde geçen notlara değinmeden evvel, devlet salnamelerinde geçen resmi nüfus verilerden bahsetmek yerinde olacaktır. ${ }^{55}$ H. 1310 (M. 1892/1893) tarihinde Beyrut sancağında 71.964'u erkek, 70.262'si kadın olmak üzere toplam 144.226 nüfus bulunmaktadır. Bu nüfus içerisinde 94. 415'i Müslüman'dır. Müslüman nüfusun 47.209'u erkek, 47.206's1

52 Şahabeddin, Beyrut, Filistin ve Nablus İzlenimleri 1918, s. 235.

53 BOA, Dâhiliye Şifre Kalemi (DH. ŞFR.) 575/25 03 Mart 1334/03 Mart 1918.

54 Ali Fuad Erden, Birinci Dünya Harbi'nde Suriye Hatıraları, Türkiye İş Bankası Kültür Yayınlar1, İstanbul 2003, s. 307.

55 “Osmanlı Devleti’nde merkezi yönetimin, askeri kurumların, vilayetlerin, bazı özel kurum ve kişilerin yıllık olarak çıkardıkları bilgilendirme amaçlı neşriyata verilen isimdir." Bilgi Aydın, "Salname", Türkiye Diyanet Vakfi Íslam Ansiklopedisi (DİA), İstanbul 2009, c. XXXVI, s. 52. 
kadındır. Gayri müslim nüfus 24.755'i erkek, 23.056'sı kadın olmak üzere 47.811 kişiden ibarettir. ${ }^{56}$ Bölgede nüfus sayımları tam manasıyla yapılmamış Arap nüfusu tamamen yazılmamıştır. Beyrut sancağında yaşayan milletler; İslam, Sünni, Dürzî, Rum Ortodoks, Marunî, Katolik, Yahudi, Protestan, Latin, Süryani, Ermeni ve Kibti'dir. ${ }^{57}$

H. 1326 (M. 1908/1909) tarihli salnamede ise Beyrut ahalisi yabanc1lar dâhil olmadığı halde; kadın ve erkek 29.544'ü İslam, 14.203'u Ortodoks, 3.689'u Katolik, 10.399'u Marunî, 421'i Protestan, 235'i Latin, 457'si Ermeni Katolik'i, 105'i Ermeni kadim ve 422'si sıbyan ve 20'si Keldânî ve 2784'u Mûsevî olmak üzere 62.279 nüfustan ibarettir. İslam ve Hıristiyan olmak üzere, Beyrut'ta bulunan 4.771 yabanc1 ile Lübnanlılar hesap edilir ise Beyrut'un nüfusu 150.000'e ulaşmaktadır. ${ }^{58}$

Numani, önce geçmişe atıf yapıp sonra kendi geldiği tarihteki nüfus bilgilerini verir: “ 1842 'de yapılan sayımda nüfus 40 binmiş, 1875 'te 70 bine ulaşmış, 1892'de ise 170 bin kişilik nüfusa ulaşmıştır. Nüfusun 33 bini Müslüman, geri kalanı ise Hiristiyan, Dürzî ve birazı da Yahudi'dir." ${ }^{59}$

Akçura ise yalnızca geldiği tarihteki nüfus verilerini yazarken bunun yanında millet dağılımına da değinir: "1912'de, Beyrut'ta 150.000 kişi yaşıyordu. Ekseriyeti Hıristiyan halk türlü dinlere bölünmüşs: 40 bin Müslüman, bin kadar Dürzî, 4 bin kadar Yahudi, kalan 100 binin hepsi Hiristiyan. Bunların 45 bin kadarı Ortodoks, 30 bin kadarı Marunî, 9 bin Obriyad, 2 bin Katolik, 2 bin Protestan, 500 Süryani, 200 Ermeni. ${ }^{\circ 60}$ Akçura'nın verdiği rakamlara göre 20. yüzyılın ilk çeyreğinde Beyrut'un yalnızca \%26'sı Müslümandır.

Beyrut şehrinde ve vilayet genelinde yaşayan Dürzî nüfus, devlet için her zaman sorun teşkil etmiştir. Daha önce bahsettiğimiz 1860-1861 Lübnan olayları ve

56 Salnâme-i Vilayet-i Beyrut, Beyrut Vilayet Matbaası, Beyrut Hicri 1310 (Miladi 1892/ 1893), s. 378.

57 Salnâme-i Vilayet-i Beyrut, Hicri 1310 (Miladi 1892/ 1893), s. 379.

58 Salnâme-i Vilayet-i Beyrut, Beyrut Vilayet Matbaası, Hicri 1326 (Miladi 1908/1909), s. 227.

59 Numani, Anadolu-Suriye-Misir Seyahatnamesi, s. 133.

60 Akçura, Suriye ve Filistin Mektupları, s. 229. 
Dürzî-Marunî çatışmalarından sonra, makalenin konusu olan tarih aralığında da (1890-1914) Dürzî olayları bitmemiştir. Silahlanan ve halkı tehdit eden Dürzîlere karşı devlet birtakım önlemler almaktan geri kalmamıştır. Örneğin; Kasım 1895'te Dürzilerin kontrol altına alınması için Selanik'ten Beyrut'a asker sevk edilmiştir. ${ }^{61}$ Bununla da yetinmeyen devlet, Beyrut yakınlarında bir askeri üs kurmayı dahi düşünmüş, ${ }^{62}$ sonra bundan vazgeçmiştir. ${ }^{63}$

\section{Eğitim, Bilim ve Kültür}

Beyrut denildiği zaman denizi, dağları, coğrafyası, mimarisi ve etnik çeşitliliği akıllara gelir. Ancak esas olarak buraya giden seyyahları en çok etkileyen, kimilerini de derinden üzen şey, şehirdeki eğitim ve öğretim faaliyetleridir. Kimilerinin üzülmesinden kasıt ise bu eğitim faaliyetlerinin büyük oranda ecnebilerin elinde oluşundandır. Modern sistemde eğitim veren birçok okula ev sahipliği yapan şehir, Müslüman okulları açısından aynı sayıyı ve kaliteyi yakalayamamıştır. Bu konu seyyahların da sıklıkla değindiği konulardan olmuştur.

Beyrut'ta gerçekleşen eğitim faaliyetleri hususunda Şibli Numani şöyle yazar: "Beyrut'ta bilimsel gelişme her ne kadar kısa süre önce başlamışsa da gelişme o noktaya kadar ulaşmıştır ki; bu bakımdan İslam ülkelerinde İstanbul'un dışında hiçbir şehir Beyrut'a denk olamaz. Bazı özelliklerinde ise İstanbul'dan ilerdedir." ${ }^{4}$

Numani'nin bu tezini kendisinden yaklaşık 15 sene sonra aynı bölgeyi gezmiş olan Babanzade de destekler: “Amerikalıların, Fransızların burada açtıkları mektepler sayesinde, şehrin hemen yarısı Fransızca ve birazı da İngilizce konuşuyor. Ahalinin fikri yönü ve tahsil derecesi; ecnebi mektepler sayesinde oldukça yüksek bir dereceye ulaşmış. O derece ki ne Rumeli'de ve hatta ne de Anadolu'nun İzmir'inde "genel kültür" denilen şey bu düzeyi bulamamış." 65

\footnotetext{
61 BOA, Sadaret Mühimme Kalemi Evrakı (A.\}MKT. MHM.), 606/2 18 CA 1313/06 Kasım 1895.

62 BOA, A. \}MKT. MHM. 606/5 25 CA 1313/13 Kasım 1895.

${ }^{63}$ BOA, A.\}MKT. MHM. 606/8 07 C 1313/25 Kasim 1895.

64 Numani, Anadolu-Suriye-Misir Seyahatnamesi, s. 136.

65 Babanzade, Beyrut'tan Kuveyt'e Irak Mektuplarl, s. 29.
} 
Numani şöyle devam eder: "Halkta edebiyat zevki o kadar yaygındır ki, çocuklar bile şiirden hoşlanmakta, şairliğe heveslenmektedir. Birçok insanın şiir kitabı vardır. Beş on kaside yazanlar ise, yüzlerce hatta binlercedir." ${ }^{66}$ Babanzade bu konuda da benzer şekilde Numani’nin tezini destekler. "Kendisini az çok tahsil görmüş kabul edenler şiir ve edebiyat ile uğraşmamayı zül (horlanma vesilesi) kabul ediyorlar." ${ }^{67}$ Tablo 1: 1891 Senesinde Beyrut Şehrinde Bulunan Misyoner Okullart ve Öğrenci Sayllart ${ }^{68}$

\begin{tabular}{|l|c|c|}
\hline \multicolumn{1}{|c|}{ Okul } & Erkek Öğrenci & Kiz Öğrenci \\
\hline Fransa Mektebi & 1520 & 2677 \\
\hline İngiliz Mektebi & 180 & 1617 \\
\hline Almanya Mektebi & 60 & 175 \\
\hline Rusya Mektebi & 160 & 210 \\
\hline İtalya Mektebi & 190 & 311 \\
\hline Yahudi Mektebi & 140 & 64 \\
\hline Amerika Mektebi & 180 & 130 \\
\hline Hususi Mektep & 3500 & 780 \\
\hline Toplam & 5930 & 5964 \\
\hline
\end{tabular}

Tablo 1'de 19. yüzyılın sonlarında Beyrut şehrinde yer alan misyoner okulları gösterilmiştir. Bu tabloda yer alan Amerikan mekteplerine ayrıca değinmek gereklidir. Bugün hala hizmet veren Beyrut Amerikan Üniversitesi (American University of Beiurt), şehir açısından oldukça önemlidir. 1866'ta Suriye Protestan Koleji (Syrian Protestant College) ismiyle kurulan bu okul, bugün Ortadoğu'nun en önemli üniversiteleri arasındadır. Kurulduğu ilk yıllarda; İngilizce, Fransızca, Türkçe, Latince ve Arapça dilleri, matematik ve Arapların eski tarihi gibi dersler okutulmuştur. Normal derslerin yanı sıra Arapça ve Arap tarihi gibi derslerin okutulması, Araplarda milliyetçilik duygularını uyandırmıştır. ${ }^{69}$ Arap milliyetçilerinin önemli bir kısmı,

66 Numani, Anadolu-Suriye-Misir Seyahatnamesi, s. 137.

67 Babanzade, Beyrut'tan Kuveyt'e Irak Mektuplarl, s. 28.

${ }^{68}$ Kürşat Çelik, “Osmanlı Hâkimiyetinde Beyrut (1839-1918)”, (Basılmamış Doktora Tezi Fırat Üniversitesi), Elazı ̆ 2010, s. 147.

${ }^{69}$ Zeine N. Zeine, Türk-Arap İlişkileri ve Arap Milliyetçiliğinin Doğuşu, (Çev. Emrah Akbaş), Gaye Kitabevi, İstanbul 2003, s. 42. 
Beyrut Amerikan Üniversitesi'nden yetişmişlerdir. ${ }^{70}$ Bu tarihte Beyrut İdadisi'nde görev yapan Mihran Boyacıyan adlı Ermeni muallimin Hristiyan okullarının oluşturduğu tehlikeyle ilgili tezkire vermesi de ilginç bir ayrıntıdır. ${ }^{71}$

Yukarıda verilen tablodan da anlaşılacağı üzere, şehirde gayri müslim okulları ve öğrenci sayıları bir hayli fazladır. Buna oranla, Müslüman okulları ve Müslüman öğrencileri azınlıktadır. Özellikle yükseköğretimde Müslümanlar yok denecek kadar azdır. Beyrut'u ziyaret eden hemen her seyyah bu durumdan şikâyet etmiştir.

Eğitimin gayri müslimlerin elinde olması hususuna değinen Babanzade şöyle serzenişte bulunmuştur: "Beyrut'un bütün halk sınıflarını ruhban eğitimden kurtarmak istiyorsak, şu anda mevcut olan ecnebi mektepleri ile rekabet edecek mektepler açmalıyız. Fransa bile Katolik eğitiminden yakayı kurtarmak için bu kadar çabaladığı halde, bizim durmamız uygun mudur?"72 Benzer düşünceler Numani'de de dile getirilir. "Bizi üzüntülere boğan şey, bu şehir İslam idaresinin bir merkezi ve Müslümanlar burada idare edenler durumunda olmasına rağmen kültürde ve medenileşmede Müslümanların Hıristiyanlarla mukayese edildiğinde çok geri planda olmasıdır"73

Mağmumi, gayri müslim okulları hakkında bilgi verdikten sonra Müslüman ilkokullarını eleştirir: "Genel eğitim çok ilerlemiş olup bir mülki idadi okulu, bir askeri rüştiye, Fransız rahipleriyle, Amerikalılar tarafından açılmış iki tıp okulu, Protestan ve Katolik okulları, sekiz on matbaa ve kütüphane bulunmaktadır. Üzülecek konu ise Müslüman İslam ilkokullarında hala eski yöntemle eğitim yapılmasıdır."74

Akçura ise bizzat ziyaret ettiği okullar hakkında ayrıntılı gözlemlerde bulunur:

“Beyrut'ta Külliye-i Osmaniye'den başka Arapların mektebi yok. Çocukların bir köşesine toplanıp bağrıșttğı, toprak üstüne hurma dallarından yapılmış derme

70 Arabizm ve Arap milliyetçiliğinin doğuşu hakkında ayrıntılı bilgi için bkz. Davut Hut, "Osmanlı Arap Vilayetleri, Arabizm ve Arap Milliyetçiliği”, Vakanüvis Uluslararası Tarih Araştırmaları Dergisi, Yıl: I, Sayı: Ortadoğu Özel, s. 105-150.

71 Selim Deringil, Iktidarın Sembolleri ve Ídeoloji (II. Abdülhamid Dönemi 1876-1909), (Çev. Gül Çağalı Güven), Doğan Kitap, İstanbul 2014, s. 119.

72 Babanzade, Beyrut'tan Kuveyt'e Irak Mektuplarl, s. 29.

73 Numani, Anadolu-Suriye-Misir Seyahatnamesi, s. 139.

74 Mağmumi, Bir Osmanlı Doktorunun Seyahat Anıları Yüzyıl Önce Anadolu ve Suriye, s. 243. 
çatma kulübeleri mektep olarak saymazsak! ${ }^{75}$ Beyrut şehrinin planina göz atınca, şehri kaplayan büyük binaların hepsinin mektep, hem de ecnebi mektebi olduğu görülüyor. Beyrut'ta pek çok mektep var; Fransızlar, Amerikalılar, İngilizler, Almanlar, Rumlar, Ermeniler, Yahudiler hatta Türkler orta, aşağı derecede mektepler yapmuşlar. En az mektebi bulunan halk, Müslüman Araplar! "76

Tüm bunlardan anlaşılan, Beyrut'a gelip giden kişilerin zihninde kalan en önemli hatıra, ecnebi mektepleri ile Müslüman mektepleri arasındaki "fark" olmuştur.

\section{Sosyal Hayat ve Halkın Yaşayışı}

Seyahatnameler, mektuplar, anılar, günlükler, hatıratlar bir bölgenin sosyal hayatına dair önemli bilgiler ihtiva eden, benzeri bulunmaz eserlerdir. Birinci elden kaynak olarak değerlendirilebilecek olan bu çalışmalara ihtiyatlı yaklaşmak gerektiği aşikârdır. Çünkü yazılanlar şahsi tecrübeye dayalı; bazen duygusal, bazen siyasal, bazen de kişisel açıdan değişkenlik gösterebilecek öznel yargılardır. Yine de bu yargılar, doğru değerlendirildiği takdirde dönemi anlamak adına en kıymetli eserlerdir. Bilhassa sosyal hayat hususunda bu eserlerin kıymet-i harbiyesi oldukça fazladır.

Beyrut halkının karakterine dair çıkarımlar yapan Babanzade, eserinde şöyle yazar: "Beyrut ahalisinde, hemen reddedilemeyecek bir açıklıkla ilk göze çarpan şey, dikkat çekici bir çalışkanlık ve bu çalışkanlığa rehberlik yapmak üzere hayret uyandıran bir zekâdır. Beyrutluların her sınıf halkında sarraflığa ve bankerliğe varıncaya kadar ticaretin her çeşidi için, özel bir kabiliyet eseri görülüyor. İşte bundan dolayıdır ki Beyrut sanatkâr bir memleketten çok, tüccar bir memlekettir." 77 Daha ziyade halkın dış görünüşü üzerinde duran Numani'nin gözlemleri şöyledir:

"Buranın dili genellikle Arapçadır. Hiristiyanlar, Yahudiler ve başkaları Arapça konuşur. Kllık klyafet biçimi Arap usulüne çok yakındır. Ama şalvar Afganistan'ın Kabillileri tarzındadır. Şalvarın iki bacağının arası fil hortumu gibi yere

\footnotetext{
75 Akçura, Suriye ve Filistin Mektuplart, s. 59.

76 Akçura, Suriye ve Filistin Mektuplarl, s. 21.

77 Babanzade, Beyrut'tan Kuveyt'e Irak Mektuplart, s. 28.
} 
doğru sarklyor. Bu ise görüntüde bir güzellik kabul ediliyor. Bir şalvar 9-10 metre kumaştan yapılabiliyor. Müslüman, Hıristiyan, Dürzî hepsi bunu giyiyor. Şüphesiz ki yeni eğitim görmüş kişiler ceket, pantolon giymeye başlamışlardır. "78

Mağmumi ise Beyrut ahalisinin çalışkanlığına değindikten sonra dil konusundaki gözlemlerini paylaşır: "Beyrut ahalisi, çalışkan ve oldukça zekidir. Yerel dil Arapça ise de Fransızca ve İngilizce çok yaygındır. Sandalcılar ve boyacılar bile bu dillerden birini anlıyor. Hâlbuki Türkçe hükümet dairesinden başka yerde konuşulmamaktadır."79

Beyrut, Müslüman bir Osmanlı idaresi altında olsa dahi yabancı etkisinin hayli fazla olduğu bir şehirdir. 19. yüzyılda gelişen Hıristiyan burjuvazisi, şehir ve liman etrafına yerleşmiştir. Ekonomik gücü olan bu grupların; siyasi, iktisadi ve entelektüel olarak etkileri hayli fazla olmuştur. Bu nedenle Avrupa sosyal hayatından esintiler, halkın yaşayışına bir hayli tesir etmiştir. ${ }^{80}$

Halkın yaşayışında bir başka dikkat çekici özellik ise öğle saatlerinde, bugün İspanya' da devam eden siesta (öğle uykusu) tarzında bir anane olmasıdır. Beyrut'ta öğle saatlerinde sokakların bomboş olduğunu aktaran seyyahlar, bu saat için İtalyanların bir ifadesi olan; "gli cani e gli Francesi” yani köpeklerden ve Fransızlardan başka kimsenin dolaşmadığı saat demişlerdir. ${ }^{81}$ Güneylilerin "öğle uykusu”, Osmanlıların ise "keyif” dedikleri bu saat, peygamber hadislerinde “öğleyin kaylûle ${ }^{82}$ yapınız. Muhakkak şeytanlar öğle vaktinde kaylûle yapmazlar” şeklinde öğütlenmiştir. ${ }^{83}$

78 Numani, Anadolu-Suriye-Misır Seyahatnamesi, s. 134.

79 Mağmumi, Bir Osmanlı Doktorunun Seyahat Anıları Yüzyıl Önce Anadolu ve Suriye, s. 243.

${ }^{80}$ Bernard Lewis, Ortadoğu (İki Bin Yıllık Ortadoğu Tarihi), (Çev. Selen Y. Kölay), Arkadaş Yayınları, İstanbul 2017, s. 403.

81 T.J. Gorton, A Beirut Anthology (Travel Wiriting Through the Centuries), The American University in Cairo Press, New York 2015, s. 89.

${ }^{82}$ Kaylule konusunda ayrıntılı bilgi için bkz. Nebi Bozkurt, "Kaylule", Türkiye Diyanet Vakfi İslâm Ansiklopedisi (DİA), Ankara 1999, c. XXV, s. 83.

83 İmam Müslim, Sahih-i Müslim Muhtasarı, (Der. Hanifi Akın), Polen Yayınları, İstanbul 2008, s. 230. 
Ulaşımla ilgili olarak, seyyahların verdiği bilgiler çok fazla değildir. Seyyahlar genelde gezip gördükleri yerleri anlatmışlar, yolculuk kısmını üstünkörü geçerek konuyu fazla uzatmamaya özen göstermişlerdir. Bu nedenle, ulaşım hususunda çok ayrıntılı malumat bulunmamakla beraber, oldukça gelişmiş bir ulaşım ağı olduğunu anlamak mümkündür. Buranın bir ticaret kenti olduğu göz önüne alınırsa, başka türlüsünün düşünülemeyeceği de aşikârdır. Beyrut; tramvay hatları, sokak lambalar1, saat kuleleri ve batı tarzı mimarinin, II. Abdülhamid ${ }^{84}$ döneminde ilk girdiği şehirlerden birisi olmuştur. ${ }^{85}$ Ulaşım araçlarının çeşitliliği konusunda en doyurucu bilgiye ise Şerafeddin Mağmumi'de ulaşmak mümkün. Kendisi Avrupa tarzı diligence arabalarından, landon ve faytonlardan, omnibüsler ve Şam'a kadar uzatılan dar hatlı demir yolundan bahseder. ${ }^{86}$

Beyrut şehri bir liman ve ticaret şehri olmasından dolayı, halkı da genellikle ticaretle uğraşmaktaydı. Bununla ilgili gözlemlerini aktaran Akçura bu durumu şu şekilde anlatmaktadır: "Parayı çok seviyorlar, hem çok iyi tüccarlar, eski Fenikelilerin kanları hala damarlarından çıkmamış. Lakin ticareti hala Finikeliler zamanındaki şekilde yapmaya çalışıyorlar. Aradan geçen birkaç bin yılı hesaba alıp üzülmüyorlar." 87 Ticaret anlamında önemli bir hareketlilik olsa da bunun hala geleneksel yollarla yapıldığı anlaşılmaktadır.

\section{Sonuç}

Makalenin genelinde, seyyahlardan aktardığımız pasajlarda da görüleceği üzere Beyrut şehri, birçok açıdan Arap yarımadasındaki diğer şehirlerden ayrılmaktadır. Bunun en bariz göstergesi, tüm seyyahların üzerinde adeta ittifak ettiği, halkın

84 Beyrut'un 1880'deki mevcut askeri, idari, eğitim ve sosyo-ekonomik yapısı ile ihtiyaçları hakkında Sultan II. Abdülhamid'e bir rapor sunulmuştur. Rapor hakkında ayrıntılı bilgi için bkz. Kürşat Çelik, "Sultan II. Abdülhamid'e Sunulan Bir Layiha: 1880 Tarihli Beyrut Layihası", Firat Üniversitesi Sosyal Bilimler Dergisi, Elazı̆̆ 2018, Cilt: XXVIII, Sayı: 2, s. 345-362.

85 Masters, Osmanlı İmparatorluğu’nun Araplarl (1516-1918) Sosyal ve Kültürel Bir Tarih, s. 211.

86 Mağmumi, Bir Osmanlı Doktorunun Seyahat Anıları Yüzyıl Önce Anadolu ve Suriye, s. 243.

87 Akçura, Suriye ve Filistin Mektupları, s. 29. 
“çalışkan" oluşudur. Arap yarımadasında nadir rastlanan bu erdem, bu şehrin karakteristik özelliklerden biridir. Yine birçok batı diline hâkim insana sahip şehir, çok dillilik ve kozmopolitlik açısından da diğer Arap şehirlerinden farklı bir hüviyete sahiptir. Ayrıca, Arap coğrafyasında en fazla yayının yapıldığı şehirdir. ${ }^{88}$ Ticaretteki maharetleri ise Arap yarımadasının büyük bölümünde görülen bir ananenin devamıdır.

Makale yalnızca Müslüman seyyahların gözüyle şehri anlatmayı hedeflemiş olsa da incelenen tarih aralığında (1890-1914) çok çeşitli ülkelerden Beyrut'a seyyahlar geldiği arşiv belgelerine yansımıştır. Örneğin; 1896'da dokuz Alman seyyah, ${ }^{89} 1901$ 'de Amerikan seyyahlar, ${ }^{90} 1903$ 'de 116 İngiliz seyyah ${ }^{91}$ ve 1904 'de 63 Fransız seyyah ${ }^{92}$ Beyrut'u ziyaret etmiştir. Devletin bu hassas bölgeye yapılan izinsiz seyahatler konusunda dikkatli olduğu ve izin almadan gelen seyyahlar hakkında işlem yaptığı yine arşiv belgelerine yansımıştır.

Beyrut, özellikle 19. yüzyılın ikinci yarısında gelişme gösteren, yük ve yolcu taşımacılığının hayli canlı olduğu bir limana sahiptir. Şehir sahip olduğu liman ile birlikte ticaret merkezi olarak da öne çıktı̆̆ından, Avrupalı devletlerin ilgisini çekmiştir. ${ }^{93}$ Beyrut'a gelen seyyahlar da çaresiz, bölge ile ilgilenen yabancı devletlerin vapurları ile ulaşımı sağlamışlardır. Bu husus seyyahların sıklıkla şikâyet ettiği bir konu olmuş, kendi topraklarında yabancı şirketlerin taşımacıllğı tekellerine almış olmaları devlet açısından bir zafiyet olarak görülmüştür.

Her ne kadar yabancıların elinde olsa da ulaşım faaliyetlerinin gelişmesi ticari canlılığın da artmasını sağlamıştır. Zaten yüzyıllardır tüccar olan halk, artan imkânlar ile bankerliğe varıncaya kadar ticaretin her çeşidi ile haşır neşir olmuştur.

88 1908-1914 tarihleri arasında Arap coğrafyasında en fazla yayın yapılan yerler: Beyrut (122), Cebel-i Lübnan (59), Şam (58). Orhan Koloğlu, Türk-Arap İlişkileri Tarihi, Tarihçi Kitabevi Yayınları, İstanbul 2017, s. 285.

89 BOA, Bab-1 Ali Evrak Odası (BEO), 77/950 21 C 1315/27 Kasım 1896.

90 BOA, Y1ldı Hususi Maruzat (Y..A..HUS.), 420/74 22 C 1319/06 Ekim 1901.

91 BOA, Y..A..HUS., 444/34 19 Z 1320/19 Mart 1903.

92 BOA, DH. MKT. 897/29 26 B 1322/06 Ekim 1904.

93 Davut Hut, "Buharlı Gemiler Çağında Osmanlı Deniz ve Nehir Yolu Ulaşımı", Osmanlı'da Ulaşım, (Ed. Vahdettin Engin, vd.), Çamlıca Basım Yayın, İstanbul 2011, s. 84. 
Şehre gelen seyyahların üzerinde durduğu noktalardan biri olan halkın tüccar oluşu, bu yüzyıldaki gelişmelerle beraber artmıştır. Elbette ticaret ve ulaşım imkânlarının artması, şehirdeki sosyal hayatı da etkilemiştir. Avrupa sosyal hayatından yansımalar, bölgeye gelen seyyahların dikkatini çekmiştir.

Şehir nüfusu hakkında ayrıntılı bilgiler veren seyyahlar, özellikle farklı etnik unsurlardan oluşan millet dağılımına dikkat çekmişlerdir. Şehirde Müslümanların dışında; Dürzi, Marunî, Mûsevî, Katolik ve Protestan milletleri nüfusun büyük bölümünü oluşturmaktaydı. Özetle Beyrut, barındırdığı farklı milletler ve kozmopolit yapısı ile Osmanlı İmparatorluğu'nun millet sistemi içerisindeki etnik mozaik yapısını yansıtan bir şehir olmuştur.

Beyrut'a gelen seyyahların hemen hepsi eğitim konusuna özellikle değinmişlerdir. Bunun sebebi, Beyrut’ta eğitim faaliyetlerinin hayli gelişmiş olmasıdır. Bu hususta kentin Osmanlı coğrafyasındaki tek rakibi; İstanbul, demek mümkündür. İngiltere ve Fransa'nın şehre olan ilgisi ticari faaliyetler ile sınırlı kalmayarak, eğitim alanında da kendini göstermiştir. Açtıkları okullarda modern eğitim sistemlerini uygulayan bu ülkeler sayesinde Beyrut halkının birçoğu, Fransızca ve İngilizce dillerini konuşabilmekteydi. Tüm bu ecnebi ve Müslüman mekteplerini gezen seyyahların hemen hepsi, yükseköğretimdeki Müslüman sayısının azlığından ve Müslüman okullarının yeterli düzeyde eğitim veremeyişinden şikâyet etmişlerdir.

Ele alınan tüm başlıklarda görüldüğü üzere, Beyrut birçok yönüyle İstanbul'u andırmaktadır. İstanbul'u andırmakla kalmayıp, onunla kıyaslanmaktadır. Bazı yönleriyle İstanbul'un önüne dahi geçmektedir. Gerçekten de Beyrut; coğrafi, etnik, dini, sosyo-ekonomik ve kozmopolitlik açısından Ortadoğu'nun İstanbul'u gibidir. Barındırdığı tüm güzelliklerin yanında, buna paralel olarak üzerinde planlar yapılan, büyük güçlerin çıkar çatışmaları altında zarar gören bir şehirdir. Beyrut'ta hiçbir şey sürekli değildir. Hayaller, umutlar, sevinçler. Ancak umutsuzluk da sürekli değildir. Yorucu, sıkıcı fakat tarifsiz şekilde güzel. Şairin de dediği gibi; pürziya, pürelvan, pürzehep, pürevrak, pürezhar, güzel Beyrut... 


\section{Kaynakça}

\section{Arşiv Kaynakları}

Başbakanlık Osmanlı Arşivi (BOA),

Dâhiliye Mektubi Kalemi (DH. MKT.) nr.1796/28, nr.198/85, nr.270/63, nr.1672/64, nr.1768/27, nr.1787/123, nr.2683/80, nr.897/29.

Sadaret Mühimme Kalemi Evrakı (A.\}MKT. MHM.) nr.606/2, nr.606/5, nr.606/8; Dâhiliye Şifre (DH. ŞFR.) nr.575/25.

Yıldız Hususi Maruzat (Y.A..HUS.), nr.420/74, nr.444/34; Bab-1 Ali Evrak Odası (BEO), nr.77/950; Beyrut Vilayet Salnamesi (1892/1893/1908).

\section{Seyahatnameler, Araştırma ve İnceleme Eserler}

Ağaoğlu, Samet, Babamın Arkadaşları, İletişim Yayınları, İstanbul 1998.

Ahmad, Anıs "Şibli Numani”, Türkiye Diyanet Vakfi İslam Ansiklopedisi (DİA), İstanbul 2010, c. XXXIX, s. 126-127.

Akçura, Yusuf, Suriye ve Filistin Mektuplarl, Ötüken Yayınevi, İstanbul 2016.

Armaoğlu, Fahir, 19. Yüzyıl Siyasi Tarihi, Timaş Yayınları, İstanbul 2014.

Aydın, Bilgi, "Salname" Türkiye Diyanet Vakfi İslam Ansiklopedisi (DİA), İstanbul 2009, c. XXXVI, s. 51-54.

Babanzade, İsmail Hakkı, Beyrut'tan Kuveyt'e Irak Mektuplar,, Büke Yayıncılık, İstanbul 2002.

Beyazıdoğlu, Hayriye, "Salnamelere Göre Beyrut (H. 1310/M. 1893-H.1326/M.1908)”, Gazi Üniversitesi Sosyal Bilimler Enstitüsü, Yayınlanmamış Yüksek Lisans Tezi, Ankara 2010.

Bilge, Mustafa, “Lübnan”, Türkiye Diyanet Vakfi İslam Ansiklopedisi (DİA), Ankara 2003, c. XXVII, s. 244-246.

Birinci, Ali, "Mehmed Suad Nam-i Diğer Ali Suad'ın Hikâyesi”, İstanbul Araştırmaları, İstanbul 1998, Sayı: IV, s. 159-180.

Bozkurt, Nebi, "Kaylule”, Türkiye Diyanet Vakfi İslâm Ansiklopedisi (DİA), Ankara 2002, c. XXV, s. 83.

Çelebi, Evliya, Günümüz Türkçesiyle Evliya Çelebi Seyahatnamesi, (Haz. Seyit Ali Kahraman), Yap1 Kredi Yayınları, İstanbul 2003.

Çelebi, Kâtip, Keşefüzzunûn, Tarih Vakfı Yurt Yayınları, İstanbul 1972. 
Çelik, Kürşat, “Osmanlı Hâkimiyetinde Beyrut (1839-1918)”, Fırat Üniversitesi Sosyal Bilimler Enstitüsü, Yayınlanmamış Doktora Tezi, Elazı̆̆g 2010.

Çelik, Kürşat, "Misyonerlerin Suriye'de Sağlık Alanındaki Faaliyetleri ile Şam Tıp Fakültesinin Açılmasına Dair Bir Rapor” The Journal of Academic Social Science Studies (JASS), Adiyaman 2014, Sayı: 29, s. 139-164.

Çelik, Kürşat, “Sultan II. Abdülhamid’e Sunulan Bir Layiha: 1880 Tarihli Beyrut Layihası”, Firat Üniversitesi Sosyal Bilimler Dergisi, Elazığ 2018, Cilt: XXVIII, Sayı: 2, s. 345-362.

Deringil, Selim, İktidarın Sembolleri ve İdeoloji (II. Abdülhamid Dönemi 1876-1909), (Çev. Gül Çağalı Güven), Doğan Kitap, İstanbul 2014.

Dursun, Davut, "Beyrut”, Türkiye Diyanet Vakfi İslam Ansiklopedisi (DİA), İstanbul 1992, c. VI, s. 81-84.

Ebü'l Fida, Ebü'l Fida Coğrafyası, (Çev. Ramazan Şeşen), Yeditepe Yayınevi, İstanbul 2017.

Erden, Ali Fuad, Birinci Dünya Harbi’nde Suriye Hatıraları, Türkiye İş Bankası Kültür Yayınları, İstanbul 2003.

Esin, Emel, “Akçuraoğlu Yusuf Bey’e Dair Hatıralar”, Ölümünün Ellinci Yılında Yusuf Akçura Sempozyumu Tebliğleri, Ankara 1987, s. 36-37.

Georgeon, François, Türk Milliyetçiliğinin Kökenleri-Yusuf Akçura 1876-1935, (Çev. Alev Er), Tarih Vakfi Yurt Yayınları, İstanbul 1999.

Gorton, T.J, A Beirut Anthology (Travel Wiriting Through the Centuries), The American University in Cairo Press, New York 2015.

Gökbilgin, Tayyib, “1840’tan 1861'e Kadar Cebel-i Lübnan Meselesi ve Dürzîler”, Belleten, Ankara 1946, Cilt: X, Sayı: 40, s. 641-703.

Güler, Mustafa, Cezzar Ahmed Paşa ve Akka Savunması, Çamlıca Basım Yayın, İstanbul 2013.

Hanioğlu, M. Şükrü, "Türkçülük", Tanzimat'tan Cumhuriyet'e Türkiye Ansiklopedisi (TCTA), İstanbul 1985, c. V, s. 1397.

Hell, Joseph, “Beyrut”, İslam Ansiklopedisi (İA), İstanbul 1961, c. II, s. 587-588.

Hinnells, John, The Penguin Dictionary of Religions, Penguin Books, London 1995.

Humpreys, R. Stephen, “XIII. Yüzyılda Eyyûbîler, Memlûkler ve Latin Doğu”, (Çev. Mustafa Kılıç), Cumhuriyet Illahiyat Dergisi, Sivas 2007, Sayı: XI/1, s. 359-378. 
Hut, Davut, “II. Meşrutiyet Döneminde Bir Osmanlı Entelektüeli Babanzade İsmail Hakkı (1876-1913)”, (Ed. Zekeriya Kurşun ve Haydar Çoruh), Tarihimizden Portreler Osmanlı Kimliği, Ortadoğu ve Afrika Araştırma Yayınları, İstanbul 2013, s. 101-122.

Hut, Davut, “Osmanlı Arap Vilayetleri, Arabizm ve Arap Milliyetçiliği”, Vakanüvis Uluslararası Tarih Araştırmaları Dergisi, Yıl: I, Sayı: Ortadoğu Özel, s. 105-150.

Hut, Davut, "Buharlı Gemiler Çağında Osmanlı Deniz ve Nehiryolu Ulaşımı”, Osmanlı'da Ulaşım, (Ed. Vahdettin Engin, Ahmet Uçar, Osman Doğan), Çamlıca Basım Yayın, İstanbul 2011, s. 71-101.

İlgürel, Mücteba, “Evliya Çelebi”, Türkiye Diyanet Vakfi İslâm Ansiklopedisi (DİA), İstanbul 1995, c. XI, s. 529-533.

İmam Müslim, Sahih-i Müslim Muhtasarı, (Der. Hanifi Akın), Polen Yayınları, İstanbul 2008.

İvanov, Nikolay, Osmanlı'nın Arap Ülkelerini Fethi (1516-1574), (Çev. İlyas Kemaloğlu ve Rakhat Abdieva), Türk Tarih Kurumu, Ankara 2013.

Keleş, Erdoğan, "Cebel-i Lübnan'da İki Kaymakamlı İdare Düzeninin Uygulanması ve 1850 Tarihli Nizamname", Ankara Üniversitesi DTCF, Tarih Araştırmaları Dergisi, Cilt: XXVII, Say1: 43, s. 131-157.

Koloğlu, Orhan, Türk-Arap İlişkileri Tarihi, Tarihçi Kitabevi Yayınları, İstanbul 2017.

Koşay, Harnit, "Yusuf Akçura", TTK Belleten, Ankara 1977, Cilt: XLI, Sayı:162, s. 389-400.

Lewis, Bernard, Ortadoğu-İki Bin Yıllık Ortadoğu Tarihi, (Çev. Selen Y. Kölay), Arkadaş Yayınlar1, İstanbul 2017.

Mağmumi, Şerafeddin, Bir Osmanlı Doktorunun Seyahat Anıları Yüzyıl Önce Anadolu ve Suriye (Çev. Cahit Kayra), Boyut Yayın Grubu, İstanbul 2008.

Masters, Bruce, Osmanlı Imparatorluğu'nun Araplarl (1516-1918) Sosyal ve Kültürel Bir Tarih, (Çev. Feray Çoşkun), Doğan Kitap, İstanbul 2017.

Nasrullah, Mehmet ve M. Rüşdü ve Mülazım M. Eşref, Memalik-i Şahaneye Mahsus Mükemmel ve Mufassal Atlas (Osmanlı Atlası), OSAV Osmanlı Araştırmaları Vakfı, İstanbul 2003.

Nerval, Gerard, Doğu'da Seyahat, (Çev. Selahattin Hilav), Yapı Kredi Yayınları, İstanbul 2014.

Numani, Şibli, Anadolu-Suriye-Mısır Seyahatnamesi, (Çev. Yusuf Karaca), Risale Yayınlar1, İstanbul 2002. 
Orha, Zafer, “Beyrut Vilayeti’nde Osmanlı İdaresi (1887-1909)”, İstanbul Üniversitesi Sosyal Bilimler Enstitüsü, Yayınlanmamış Doktora Tezi, İstanbul 2017.

Ortaylı, İlber, Tanzimat Devrinde Osmanlı Mahalli İdareleri (1840-1880), Türk Tarih Kurumu, Ankara 2018.

Ortaylı, İlber, “Osmanlılar'da Millet Sistemi”, Türkiye Diyanet Vakfi İslâm Ansiklopedisi (DIA), İstanbul 2005, c. XXX, s. 66-70.

Suad, Ali, Suriye, Irak, Necid ve Hicaz Seyahatlerim, (Haz. Zekeriya Kurşun ve Ali Okumuş), Taş Mektep, İstanbul 2015.

Şahabeddin, Cenab, Beyrut, Filistin ve Nablus İzlenimleri 1918, (Haz. Tayfun Haykır), Ötüken Neşriyat, İstanbul 2015.

Günaltay, Mehmed Şemseddin, İslam Tarihinin Kaynakları Tarih ve Müverrihleri, Kitabevi, İstanbul 1991.

Temimi, Mehmed Refik ve Mehmed Behcet, Beyrut Vilayeti I. Cenub Klsmı (1333-1335), Beyrut Vilâyet Matbaası, Beyrut 1917.

Temir, Ahmet, Yusuf Akçura, Kültür ve Turizm Bakanlığı Yayınları, Ankara 1987.

Togay, Muharrem Feyzi, Yusuf Akçura'nın Hayatı, Hüsnütabiat Basımevi, İstanbul 1944.

Uygun, Süleyman, Osmanlı Sularında Rekabet (Mesajiri Maritim Vapur Kumpanyası 18511914), Kitap Yayınevi, İstanbul 2015.

Ünver, Metin, “Courtgi (Gürcü) Bahr-i Sefid (L’egee) Vapur Kumpanyası 1883-1911”, Çanakkale Araştırmaları Türk Yıllı̆̆ğ, Bahar 2018, Sayı: XXIV, s. 175-210.

Zeine, N. Zeine, Türk-Arap İlişkileri ve Arap Milliyetçiliğinin Doğuşu, (Çev. Emrah Akbaş), Gaye Kitabevi Dağıtım, İstanbul 2003. 